\title{
Criminal justice in a small Nordic country: The case of Iceland
}

Helgi Gunnlaugsson, professor, University of Iceland

\begin{abstract}
Crime concerns have deepened in Iceland in the new millennium. The number of criminal court decisions increased until 2013, when it temporarily levelled off before reaching a new peak in 2019. This development has put pressure on the prison system, as a long list of convicts awaiting completion of their sentences has accumulated. This paper uses official data, previous research and media accounts to examine the response of Icelandic authorities to this trend. One of the main questions addressed in the article is whether the criminal policy adopted by Icelandic authorities suggests a movement toward punitive or non-custodial measures. As it turns out, the Icelandic prison system has undergone major changes to meet this penal challenge. A new modern prison has recently been built close to Reykjavík to replace three smaller, older facilities that have been closed. This suggests a punitive turn. Yet at the same time, non-custodial sanctions have been increasingly introduced and implemented in lieu of sentences to closed security prisons. These non-custodial sanctions include electronic surveillance, additional community service work and an increased possibility to serve time in open prison units. It is contended here that a combination of practical budget concerns and rehabilitation sentiments lies behind this criminal policy development.
\end{abstract}

\begin{abstract}
Kriminaliteten i Island har skabt voksende bekymringer i det nye årtusind. Antallet af strafferetlige afgørelser var stigende indtil 2013, hvor det fladede ud for en tid. Men i 2019 nåede antallet nye højder. Denne tendens har skabt et pres inden for fængselssystemet, der bl.a. viser sig i ophobning af domfældte, der må vente på at afsone deres dom. I denne artikel undersøges de islandske myndigheders reaktion på denne udvikling på baggrund af officielle data, tidligere forskning og mediernes dækning. Et af de mange spørgsmål, der bliver stillet i denne artikel, går ud på hvorvidt den islandske kriminalpolitik går i retning af mere eller mindre indespærring. Det islandske fængselssystem har gennemgået gennemgribende ændringer. Et moderne
\end{abstract}


fængsel er for nylig blevet opført i umiddelbar nærhed af Reykjavik, hvilket ville antyde en straffende tendens, mens tre mindre og ældre fængselsinstitutioner er blevet lukket. Samtidigt har myndighederne i stigende grad anvendt ikke-frihedsberøvende straffe som alternativ til de lukkede fængsler. Blandt de nye metoder er elektronisk overvågning, mere samfundstjeneste og øgede muligheder for afsoning $\mathrm{i}$ åbne fængsler. Artiklen vil vise, at såvel budget- som resocialiseringshensyn står bag denne udvikling i straffepolitikken. Artiklens danske titel er: Straf $\mathrm{i}$ et lille nordisk land: Tilfældet Island.

\section{Key words:}

Prison policies, non-custodial sanctions, Scandinavian exceptionalism, recidivism, foreign prisoners.

Fængselspolitik, ikke-frihedsberøvende straf, skandinavisk ekseptionalisme, recidiv, udenlandske fanger.

\section{Introduction}

The Icelandic prison system has undergone major changes in the new millennium. A new prison at Hólmsheiði, close to Reykjavík, was opened in 2016, and two older prison facilities were closed down at the same time. Open-prison units have significantly been increased. In the beginning of the millennium, about a dozen open-prison spaces were available, but in 2020, the number of such options had been increased to more than 40 . The total prison space did not change much during this time period until the opening of the new prison in Reykjavik, with close to a total of 200 prison spaces available in early 2020. Non-custodial sanctions - electronic surveillance, more community service work and increased possibility to end completion of a prison sentence at a halfway house - have, moreover, increasingly been introduced and implemented instead of serving time in prison. Additionally, younger offenders have, since 2016, been able to receive parole after one-third of their sentence served in prison, instead of half of the sentence previously.

These trends in sentencing practices can easily be interpreted as a tendency toward less punitive measures adopted by local prison authorities, being more lenient and humane over time in the new century. Gradually moving away from unconditional imprisonment as a main policy measure increasingly adopting non-custodial sanctions instead. At the same time, as the tendency to make less use of prison space has taken place, the number of criminal court cases has steadily grown, resulting in more cases awaiting processing and completion by prison authorities. More than 600 persons were placed on a waiting list at the Prison and Probation Administration in the spring of 2020, with the total length of imprisonment decided by the criminal courts significantly increasing between 2018 and 2019. With this background in mind, the minister of justice appointed an expert commission in early 2020. The main task of the 
commission was to prepare proposals to shorten the list of convicts awaiting completion of their sentence, without undermining the deterrent function of the criminal justice system as stated in the assignment. This author was one of the members of the commission. The group submitted their proposals to the justice ministry with a report in the summer of 2020 (Justice Ministry Report, 2020).

In this article, the Icelandic prison system and its developments in this century will be examined. First, the prison facilities will be described along with the causes of incarceration and distribution of criminal court decisions for the prison sentences during 2009-2019. Studies on local recidivism and the number of foreigners in Icelandic prisons over time will briefly be reviewed. Recent developments in prison alternatives in Iceland will also be analysed in more detail.

Where does Iceland belong in a crime-control-comparative perspective? Can Iceland be described as exceptional in penal terms as Pratt (2008 and 2009) has described other Nordic nations, in particular Norway? Why has Iceland adopted more lenient non-custodial options in recent years? Is an informed rehabilitation policy guiding policymakers or is it more practical budget concerns, or perhaps a mixture of both? Finally, the proposals of the justice ministry commission to shorten the waiting list will be outlined.

\section{Icelandic Prison Situation}

The state owns and runs all prison facilities in Iceland (Prison and Probation Administration, 2020). The Prison and Probation Administration, established in 1989 and modelled after similar Scandinavian organisations, oversees daily operations of all facilities. Iceland's prisons have been divided into two categories. One for prisoners serving sentences, and the other for those held in custody and solitary confinement during the initial investigation of their cases (Gunnlaugsson, 2011, 2019).

In early 2020, five prisons, in which convicted prisoners served their sentences, were operating in Iceland, with a total of about 200 prison cells (Pakes \& Gunnlaugsson, 2018). One of the prisons is located in the Reykjavík vicinity and the others are scattered across various regions of the country - two in Southwest Iceland (Litla-Hraun and Sogn), one in Western Iceland (Kvíabryggja) and one in the largest town of Northern Iceland (Akureyri). Only the new Reykjavík prison was originally built as a prison facility. The other buildings were all renovated to serve as prison facilities after originally having been planned for other purposes. The Reykjavík prison in Hólmsheiði opened in late 2016, replacing an old prison in downtown Reykjavík, which was closed in May of 2016. The new Reykjavík prison has cells for 56 prisoners, including a custody facility. This facility is mainly used as a reception unit for in-coming prisoners, females, shorter prison sentences and for those who fail to pay fines. 
The custody facility was, for a long time, located in the largest prison at LitlaHraun but was moved to the new prison in Hólmsheiði in 2017. The Litla-Hraun Prison appears close to a maximum-security facility, located next to two small villages about $60 \mathrm{~km}$ southeast of Reykjavík; it is surrounded by a high transparent chain-link metal fence. About half of the total prison population is placed there -87 spaces. It includes the custody facility, which has now found a new function for prison staff and family visits.

Before 1989, no prison for females existed in Iceland, and they were placed among other male inmates. The Kópavogur Prison was opened in 1989, and there, all female inmates served their sentences for more than a quarter of a century until it was discontinued in 2015. Usually, fewer than ten female inmates served time at any given time in the Kópavogur Prison and the rest of the maximum capacity of twelve was filled with male inmates. The new prison in Hólmsheiði includes a separate division for women prison inmates, and they started serving their terms there in November of 2016.

The prison facility in Akureyri, in the north of Iceland, is located at the local police station and was renovated about a decade ago. It had a capacity for 10 inmates, mostly intended for shorter sentences. In 2020, the justice ministry announced plans to close this facility for good due to the high cost of operating such a small unit. These plans materialised in September of 2020 (Ólafsdóttir, 2020; Ciric, 2020), leaving Iceland with a total of four prisons instead of five. In addition, the prison in the northwest of Iceland, Kvíabryggja, looking more like any other farmhouse, is virtually an open-prison facility. This prison has a capacity for 22 inmates and has recently been renovated. Finally, in 2012, a new open-prison facility, Sogn, was opened not far away from Litla-Hraun, with a capacity for up to 20 inmates. These two open-prisons, Kvíabryggja and Sogn, were recently examined by an international scholar (Pakes, 2020).

With the new prison in Hólmsheiði, the total prison capacity in Iceland was significantly increased, or up to a total of 186 cells (Vernd, a half-way house, not included, discussed in more detail here below). However, prison authorities have not been able to use the new expansion to its maximum because of the lack of funding and staff. In February of 2020, a total of 159 served time in prison in Iceland, including 27 held in custody while their case was investigated by police. Of this total, 41 served time in an open-prison facility. Of those serving a sentence in prison, ten inmates were females. Typically, more than 60 percent of the inmate population is 35 years and younger. The Icelandic per capita incarceration rate is comparatively low, or around 37 per 100 thousand inhabitants, below almost all other European nations including Nordic nations (World Prison Brief, 2020).

Even though the number of prisoners does not necessarily reflect the crime rate in society, this figure implicitly tends to support the notion of Iceland as a low-crime country. Perhaps Iceland might even be a better candidate for penal exceptionalism than the other Nordic societies, typically portrayed as being exceptional (Pratt, 2008, 2009). Iceland's prison rates, like Faroe Islands 
and Åland (Lauritsen, 2019), are lower than those of the other Nordic nations and the prisons are even smaller. Moreover, the tiny prison estate in Iceland includes open-prisons in addition to the half-way house, Vernd, suggesting Iceland to be a fertile ground for a positive prison system no less than the other Nordic nations.

In 2020, prison authorities had plans to hire more prison staff for Hólmsheiði Prison in order to make more use of this facility. With the closing down of Akureyri Prison, more funds are planned to be allocated to Hólmsheiði Prison. Hólmsheiði is more economic than the small unit in Akureyri, and up to 20 more inmates are expected to serve there in the future; it is on the same budget as Akureyri Prison. If Hólmsheiði Prison will be used to its maximum, the prison rate is bound to increase somewhat, up to 50 per 100 thousand inhabitants.

\section{The New Reykjavík Hólmsheiði Prison}

The new modern prison in Hólmsheiði appears, from the outside, to be more security oriented than a humane facility, surrounded by a high transparent metal fence. It is placed upon a heathland close to Reykjavík, down in a secluded small valley off the main road, with rather limited outside view. It is considered to be a maximum-security institution without any units being open, organised around different wings and units. The prison looks to be a bit impersonal and sterile, with white inside-walls and a prison staff control room in the middle of the building like some sort of an invisible bunker where different wings are monitored. Yet, everything is new and fresh, especially designed as a prison, unlike other prison buildings in Iceland.

In terms of construction, Hólmsheiði Prison symbolises a step forward for Iceland prisons, replacing aging and worn-out facilities - including a new improved custody unit replacing the old one located at Litla-Hraun. The custody unit at Litla-Hraun was impractical when investigating a criminal case; for example, to transport legal personnel and police between Reykjavik and Litla Hraun (approx. 60 kilometres) for interrogation of crime suspects. Moreover, both frequent use of solitary confinement and the aging facility at Litla-Hraun had been criticised by international bodies like the UN Committee Against Torture for inhumane conditions (RÚV, 2017b). With the new facility at Hólmsheiði, this custody process is at least smoother in the close vicinity of Reykjavík and provides better quality of the facilities themselves.

Improved facilities for educational purposes are also provided for in the new prison, in addition to workshop rooms. The new prison is formally only intended for those entering the prison system and for those serving shorter sentences, yet with a special unit for women prison inmates, who will most likely serve longer there than most men will, as Hólmsheiði prison is the only prison specifically intended for women. Female inmates, however, also have the possibility to be transferred to open prison facilities just like men. 


\section{Icelandic Prison Statistics}

Institutional records of prisoners for 2009-2019 (Table 1) show stability with some fluctuations hovering around a total of 300-370 inmates serving time in prison each year. The number of inmates incarcerated each year reflects institutional capacity more than prison demand and number of court-sentencing decisions. Stability is most evident during 2010-2015, when up to $100 \%$ of available prison space was used each year or at least higher than the $95 \%$ capacity prison authorities regard as their security limit (Justice Ministry Report, 2020). After 2015, use of prison space dropped somewhat to as low as $80 \%$ of the total capacity; this occurred due to the aging facilities being taken out of function. The new prison in Hólmsheiði opened in late 2016 and increased the total prison capacity significantly but has not yet been used to its maximum due to, as previously mentioned, lack of funds and staff.

Table 1. Percentage of inmates in Icelandic prisons by type of crime 2009-2019

$\begin{array}{lllllllllll}2009 & 2010 & 2011 & 2012 & 2013 & 2014 & 2015 & 2016 & 2017 & 2018 & 2019\end{array}$

\begin{tabular}{lccccccccccc}
\hline Homicide & 7 & 7 & 6 & 7 & 7 & 7 & 7 & 8 & 6 & 6 & 7 \\
Property crime & 24 & 26 & 25 & 26 & 22 & 23 & 25 & 24 & 17 & 16 & 15 \\
Traffic & 9 & 3 & 5 & 8 & 7 & 5 & 7 & 3 & 9 & 9 & 12 \\
Drugs & 30 & 35 & 30 & 28 & 30 & 30 & 31 & 35 & 35 & 40 & 40 \\
Sexual crime & 10 & 12 & 12 & 12 & 14 & 14 & 11 & 12 & 14 & 12 & 11 \\
Violence & 10 & 11 & 14 & 12 & 14 & 15 & 13 & 10 & 13 & 13 & 11 \\
Other & 10 & 6 & 8 & 7 & 6 & 6 & 6 & 8 & 6 & 4 & 4 \\
\hline \hline Total number of inmates & $\mathbf{3 2 8}$ & $\mathbf{3 2 6}$ & $\mathbf{3 6 6}$ & $\mathbf{3 8 9}$ & $\mathbf{3 7 3}$ & $\mathbf{3 5 2}$ & $\mathbf{3 4 8}$ & $\mathbf{2 8 5}$ & $\mathbf{2 9 8}$ & $\mathbf{3 2 2}$ & $\mathbf{3 6 4}$ \\
\hline \hline
\end{tabular}

Source: Prison and Probation Administration annual reports 2009-2019

As for the causes of incarceration, Table 1 shows an emphasis on confining those convicted of drug, property and different types of violent offenses. The ratio of drug offenders to the overall prison population in this time period varied from 30 to 35 percent; this was until 2018 and 2019, when the ratio jumped to 40 percent of the total inmate population. In 2012, for example, a total of 108 inmates served time in prison for drugs. In 2016, this number stood at 100 inmates and finally, the number peaked at 142 in 2019. The ratio of drug offenders in prison has increased markedly in the new millennium. In the early 1990s, less than ten percent of the total inmate population served time in prison for drug offences (Gunnlaugsson \& Galliher, 2000).

Proportionately, property offenders in prison have decreased somewhat, from accounting for about 26 percent of all inmates in 2010 down to a low of 15 percent in 2019 (Table 1). Violent offenders, which included inmates committing homicide, sexual crimes and other violence, took more space in prison; this was from a total of 27 percent of all inmates in 2009 up to 36 
percent in 2014. After that, the proportion went down again, to a similar rate as in 2009, to about 29 percent in 2019. Both proportionately and in number, the most notable change during this time period, therefore, consists of increasingly more drug offenders while traffic and property violators have been lagging behind.

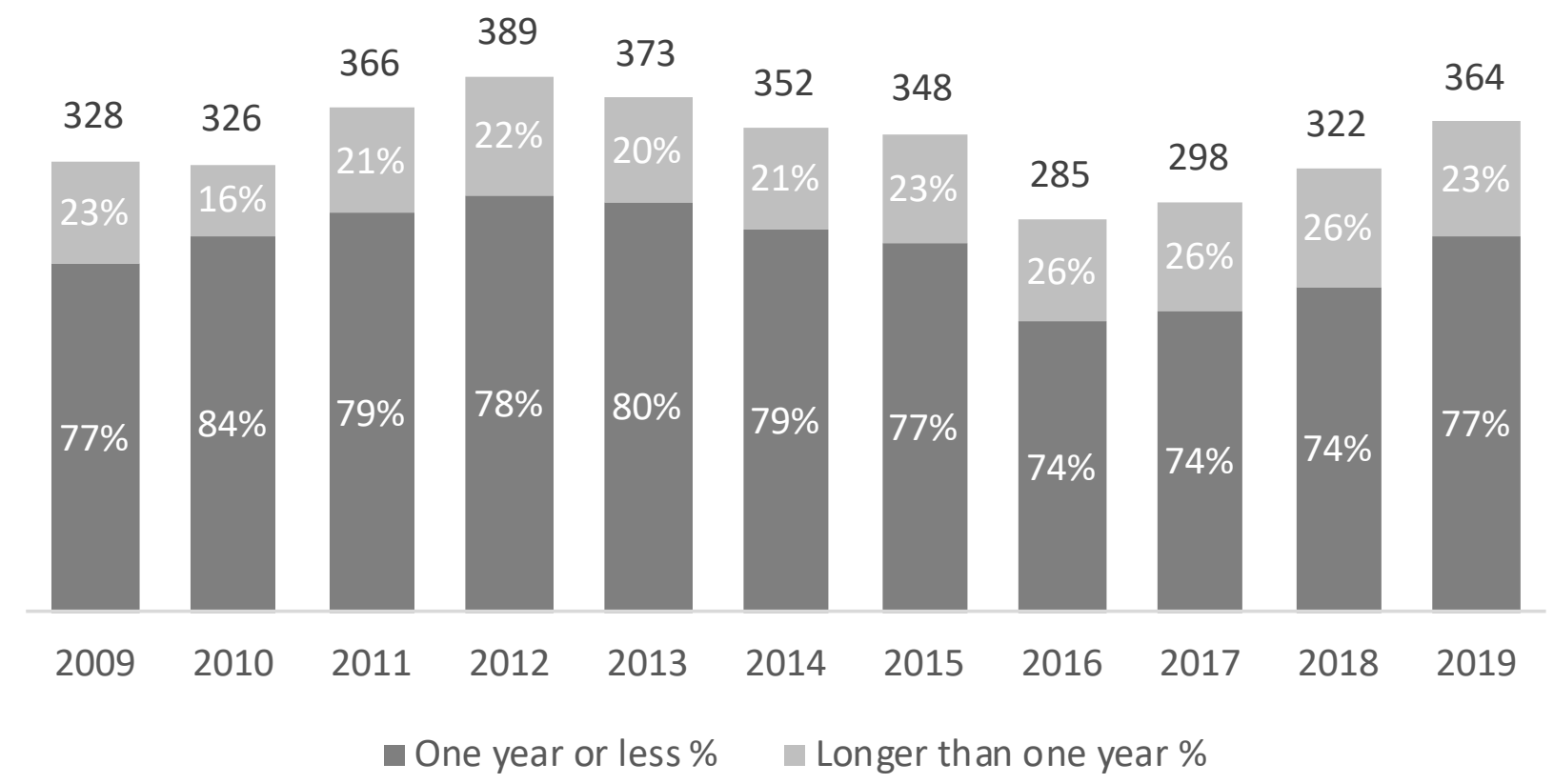

Figure 1. Number and percentage of inmates $2009-2019$ by length of time served Source: Prison and Probation Administration annual reports 2009-2019

If the length of actual imprisonment is analysed during 2009-2019 (Figure 1), no major changes can be detected over time. The vast majority, or about 74-84 percent of all inmates, served one year or less in prison during this tenyear period. Despite some fluctuations, the same percentage, 77 percent of inmates in 2009 and again in 2019, served one year or less in prison.

Overall, prison sentences decided by the criminal courts tend to be relatively short (Table 2). In 2009, the length of about 60 percent of all prison sentences were three months or less, with a slightly lower proportion in 2019, at about 57 percent. In the 1980s, about 66 percent of all prison sentences were three months or shorter (Gunnlaugsson \& Galliher, 2000), with the rate being somewhat lower during 2009-2019. Thus, it appears that the ratio of shorter prison sentencing of three months or less has slightly decreased over time, from being about two-thirds of all sentencing in the 1980s down to 60 percent or even less in 2009-2019. Yet this is an uneven trend and not a major one. It is important to keep in mind that sentences shown in Table 2 are not all served in prison. A large part is completed through non-custodial sanctions such as community service, discussed in more detail here below. 
Table 2. Percentage of criminal court decisions by length of prison sentence 2009-2019

$\begin{array}{lllllllllll}2009 & 2010 & 2011 & 2012 & 2013 & 2014 & 2015 & 2016 & 2017 & 2018 & 2019\end{array}$

\begin{tabular}{lccccccccccc}
\hline Less than 30 days & 27 & 25 & 27 & 30 & 26 & 25 & 28 & 27 & 30 & 26 & 27 \\
30 days-3 months & 33 & 31 & 34 & 29 & 29 & 35 & 34 & 33 & 28 & 31 & 30 \\
3-6 months & 16 & 13 & 17 & 15 & 18 & 16 & 15 & 16 & 18 & 16 & 16 \\
6-12 months & 8 & 13 & 9 & 12 & 10 & 11 & 12 & 12 & 12 & 14 & 14 \\
12-36 months & 11 & 13 & 11 & 8 & 13 & 9 & 7 & 7 & 9 & 10 & 10 \\
$36+$ months & 5 & 5 & 2 & 6 & 4 & 4 & 4 & 3 & 3 & 3 & 3 \\
\hline \hline Total number of court decisions & 447 & 407 & 477 & 493 & 563 & 531 & 492 & 530 & 504 & 426 & 568 \\
\hline \hline Total length of punishment in years & 329 & 309 & 296 & 336 & 423 & 336 & 286 & 318 & 286 & 247 & 373 \\
\hline
\end{tabular}

Source: Prison and Probation Administration annual reports 2009-2019

What about the proportion of longer prison sentences? There, the trend appears to be somewhat different (Table 2). In 2009, about 16 percent of all prison sentences included a prison sentence of one year or longer, but in 2015, this proportion had dropped to about 11 percent of all prison sentences, and in 2019, this figure stood at 13 percent. A similar trend can also be detected with the ratio of sentences longer than three years. Five percent of all sentencing was three years or longer in 2009, going down to 3 percent of the total in 2016-19, as shown in Table 2. The ratio of long sentencing overall has, therefore, been decreasing. The notable increase observed in the total number of criminal court decisions over time, thus, appears to include more shorter sentences than longer ones.

Overall, a growing number of prison sentences decided by the criminal courts can be detected between 2009 and 2019, more than a 20\% increase (see Table 2). A peak was reached in 2013, with a total of 563 individuals receiving a prison sentence, going down to 492 in 2015. An increase was observed again to 530 in 2016, with a notable drop in both 2017 and 2018. In 2019, the number of prison sentencing, however, jumped again to a total of 568 or slightly higher than the previous peak in 2013 as shown in Table 2.

We also see an increase in the total length of sentencing from 2009 to 2013, with a notable drop taking place in both 2014 and 2015 (Table 2). The total length of prison sentences meted out by the courts in 2009 was 329 years in prison, but in 2013, this total had jumped to around 423 years, an increase of about one-third. In 2014 and 2015, we see a marked drop down to a total of 286 years in prison, markedly lower than 2009 . Thus, the number of prison sentences meted out by the courts each year, therefore, had a significant impact on the total length of imprisonment. In Table 2, we see the total length of punishment reaching a peak in 2013, with a notable drop after that. In 2019 however, both the total number of sentences and the total length of punishment in years reached a new peak again.

This trend in more criminal court decisions, yet uneven during 2009-2019, apparently has contributed to the pressure in the prison system, adding to the long list of convicts awaiting completion of their sentence. In 2017 for 
instance, the number of those awaiting to serve their sentence stood at 450 (Arnarsson, 2017), and as previously mentioned, this number had reached to more than 600 in 2020. However, the vast majority on this waiting list had received short prison sentences, eligible to non-custodial sanctions in many cases (Justice Ministry Report, 2020). Those with longer sentences for more serious crimes typically start serving their sentence in prison immediately or shortly after the court decision.

\section{Prison Practices and Non-Custodial Sanctions}

As pointed out earlier, court prison-sentencing policy is one thing and time completed in prison quite another. Paroles, for instance, have increasingly been granted over the years. In the time period 2000-2008, about 40 percent of the prison population completed the full sentence in prison, while about 60 percent were granted parole before the whole term was served. In 2008, only about one-fourth completed the whole term and more than 70 percent were granted parole. This trend of granting more parole had started earlier. During the 1980s and 1990s, increasingly more prisoners were granted parole, from about 36 percent in 1985 to 57 percent in 1998 (Gunnlaugsson \& Galliher, 2000). Also important to keep in mind is that those receiving a prison sentence of 12 months or less (since 2016) may also be eligible for community work instead of serving time in prison. Therefore, many of those receiving a 12-month unconditional prison sentence or less from the criminal courts, as shown in Table 2, never do serve time in prison and, therefore, do not appear in Table 1. Decision of community work instead of serving time in prison is taken by Prison and Probation Administration and not the criminal courts, a typical procedure in other Nordic countries.

Proportionately, more prisoners have been granted parole in recent decades, while at the same time, we see a growing number of prison sentences. According to Iceland's penal code (law no. 19, 1940), an option of giving parole is made possible when two-thirds of the term has been served and after at least two months in prison. Yet, there are frequent exceptions, and many prisoners are released when half of their term is completed.

With the new prison legislation passed by Alpingi in 2016 (Prison Bill, Law no. 15, 2016), convicts younger than 21 years old can be released from prison when one-third of their sentence has been served in prison (article no. 80). The relative share of half and two-thirds of terms completed before being released on parole has not changed much over time. With a growing number of longer sentences over time, more inmates have a possibility to be granted parole since sentences shorter than two months do not permit it. 


\section{Repeat Prisoners}

In the 1980s and 1990s, typically about half of the prison population had served time in prison before (Gunnlaugsson \& Galliher, 2000). In the new millennium, the rate of repeat servers has somewhat fluctuated. During $2000-$ 2008, for instance, repeat prisoners ranged from 56 percent in 2001, down to about 41 percent in 2008. In 2009, about 60 percent of the inmates were first-time servers, peaking at 68 percent in 2013, but then dropping again to 54 percent in 2016 (Figure 2). What accounts for this uneven trend is, however, difficult to explain. A growing number of prison sentences decided by the courts during the first decade of the century appears to have reached more new offenders with the ratio of repeat offenders going down. More services provided to prisoners have been offered while they are serving their term; these include substance abuse treatment and measures possibly helping to reduce recidivism. A Nordic study on prison relapse showed Iceland coming second to Norway with the lowest recidivism rates (Kristoffersen, 2013). Still, it is important to keep in mind that comparative studies of this type are always difficult; for instance, whatever is being defined as a relapse in one country can complicate the picture.

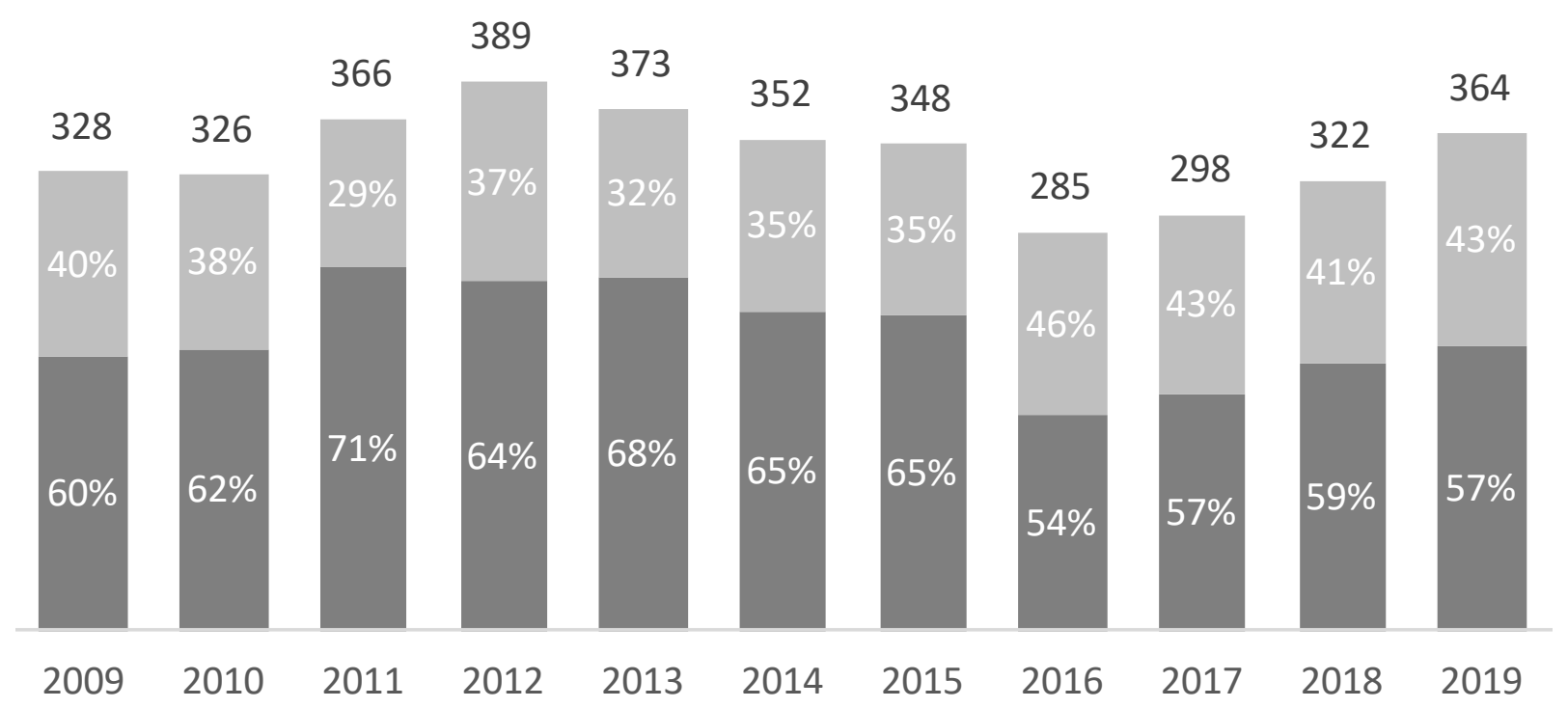

First servers \% $\quad$ Served before \%

Figure 2. Number and percentage of first servers in prison and served before 2009-2019

Source: Prison and Probation Administration annual reports 2009-2019

Earlier, Baumer et al. (2002) had found Iceland to have a similar rate of recidivism as in other nations for both reconviction and reimprisonment. Therefore, a small and relatively homogenous nation, such as Iceland with a low crime rate, was not found to reintegrate offenders at a higher rate than others. 
While there are perhaps several plausible explanations for this pattern, the authors raise the possibility that functional aspects of exclusion may override prevailing re-integrative forces, even in communitarian societies such as Iceland, which is characterised by low crime rates. Recent figures of repeat prisoners seem, in this respect (Figure 2), to indicate some stability hovering around 40-45 percent of the inmate population having served time in prison before, or close to what (Baumer et al., 2002) had earlier found in many other Western countries.

\section{Foreigners in Icelandic Prisons}

During the economic boom in the first decade of the new millennium, Iceland experienced an influx of foreign visitors and residents. About $2.4 \%$ percent of the population was foreign born in 1999, increasing to 10 percent in 2010. In the aftermath of the banking collapse in 2008, followed by an economic expansion fuelled by explosion in tourism, the figure rose to a 15 percent peak of immigrants in 2020 (Statistics Iceland, 2020). Most immigrants came from the eastern parts of Europe to meet the expanding demands of the labour market. The population increase in Iceland (pop. 365 thousand) during the past few decades, therefore, comes in large part from foreigners. The new social environment of foreign-born inhabitants, and an increasing number of foreign visitors to Iceland, can also be detected in the local criminal justice system.

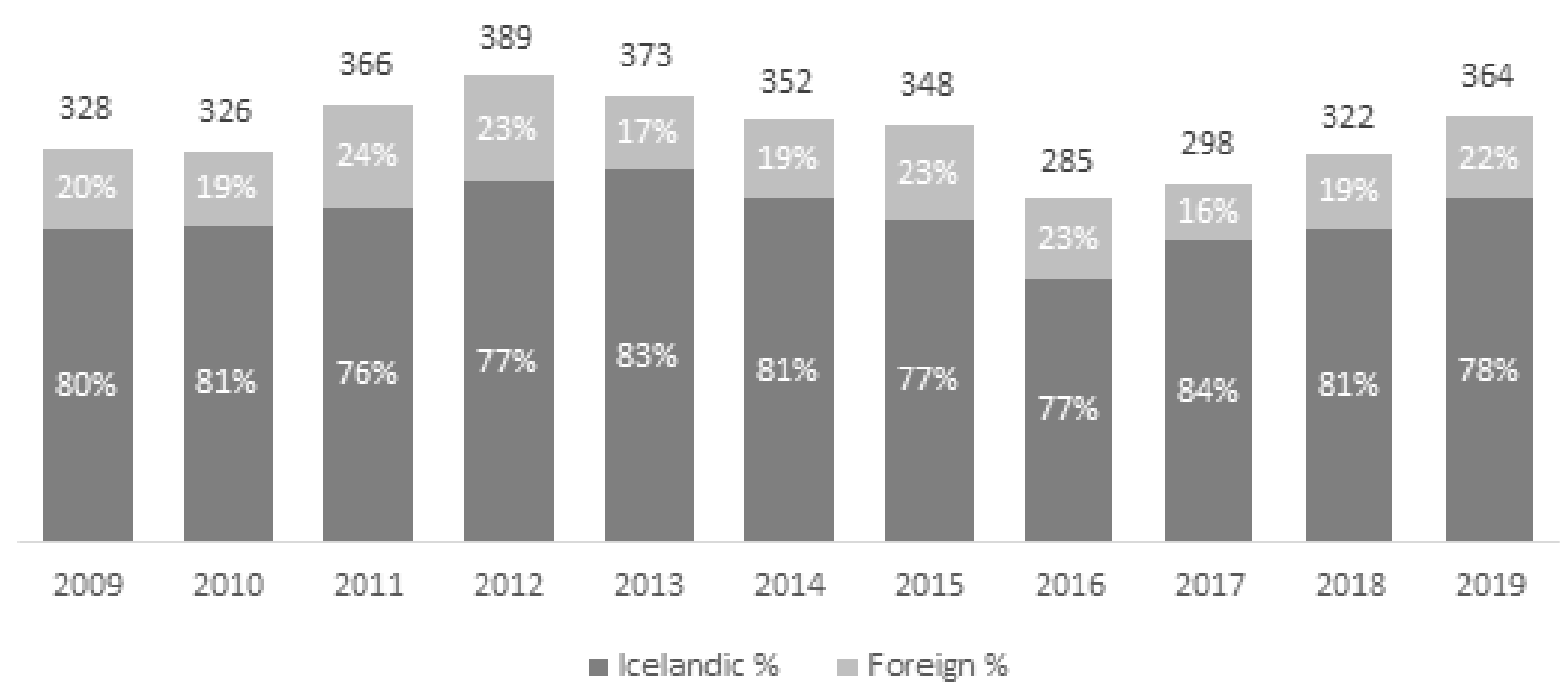

Figure 3. Number and percentage of Icelandic and foreign inmates 2009-2019 Source: Prison and Probation Administration annual reports 2009-2019

On average, about two foreign-born citizens served time each day in Icelandic prisons in 2000, but they numbered 24 in 2008, about 17 percent of the total inmate population. In addition, six foreigners were held in custody while their 
cases were being investigated by the police (Gunnlaugsson, 2019). In 2011, the total number of foreign-born inmates had increased to 89 inmates serving time over the whole year, about 24 percent of the total inmate population serving time in prison for that year (Figure 3). The ratio of foreign prisoners has, however, lowered somewhat in most recent years. In 2019, about 22 percent of the inmate population was foreign born, a total of 70 individuals. Most of these prisoners served time in prison for the first time and were, therefore, new to the prison system and, thus, help explain lower relapse rates.

As previously indicated, the proportion of foreign residents in Iceland was 15 percent in early 2020, a bit lower than the percentage of foreign prisoners. Yet demographics of immigrants are probably somewhat different than of the native population. There are more younger males among immigrants in addition to visiting tourist inmates who are not permanent residents of Iceland. This aspect of foreigners in prisons, however, needs to be explored in more detail to adequately answer the question whether foreigners are over-represented in Icelandic prisons.

The prison pressure so evident in Iceland in recent years, resulting in a long waiting list of convicts, was, in a large part, due to the ever-increasing heterogeneous nature of Icelandic society. The types of crimes committed by foreign-born inmates tend to be similar with those committed by local inmates. Property crimes and drug and violent offenses constitute the bulk of the offenses committed by foreign citizens who serve time in prison during this period.

\section{Prison Alternatives in Iceland}

Alternatives to prison have increasingly been adopted in recent decades in Iceland. Community work has been possible since 1995, and since 2016, it is possible for those who have received a 12-month unconditional prison sentence or less. The Prison and Probation Administration can decide that the sentence may be executed in the form of unpaid community service, lasting a minimum of 40 hours and a maximum of 480 hours. Up to two hundred persons have served their time doing community service work each year instead of doing time in prison. Electronic monitoring has been offered since 2012, now for those who have received a more than 12- month unconditional prison sentence or more; this has enabled an earlier release from prison than before (back-door policy). Those who are nearing completion of a long prison sentence and have secured a job, or follow an education program, are also eligible to serve their sentence at Vernd, a half-way house in Reykjavík, run by a private non-profit organisation, before being electronically tagged at home or work. Each day, more than 20 persons served their sentences at the half-way house in 2019. 
If we take an example of a person receiving a 3-year unconditional prison sentence from the criminal courts, he/she might be released on parole after half of the 3-year prison term served in prison, a typical procedure for quite many first-time offenders and non-violent offenses in Iceland. This person might serve a total of 10 months in an open or locked prison, five months at the half-way house in Reykjavík and eventually three months by electronic monitoring before being released on parole for the remaining half of the prison sentence. Despite this apparent prison leniency (Prison Bill, 2016), an ever-increasing waiting list has accumulated in recent years, as mentioned above.

These alternatives to prison indicate a tendency in Iceland to introduce punishment types with potential rehabilitation qualities in dealing with crime control. At the same time, these measures reduce government expenditures on prisons, being less costly and are, thus, politically attractive. Moreover, these alternatives help reduce the pressure on prison facilities. Most convicts selected for these programs early on were nonviolent offenders, convicted of property offenses or violation of traffic laws. Later, this prison leniency has also reached other offenders as well, further helping to easing the pressure on the prison system.

\section{Prison Commission Proposals}

In 2009, about two hundred persons were on a waiting list to serve their sentence while in 2020, the list had reached more than 600 persons. In March of 2020, the minister of justice, therefore, appointed an expert commission to prepare proposals to help shorten the waiting list of offenders. The reason for this increase, as mentioned above, is a trend, yet uneven, toward more criminal court decisions received by prison authorities in recent years. In addition, we see a trend in more use of prison spaces for custody purposes while investigating a criminal case at the expense of regular prison spaces. Moreover, lack of funding especially evident with the new prison at Hólmsheiði in Reykjavík, not being able to use all spaces to its maximum, has also contributed to the pressure building up in the system.

The first task of the commission was to explore the nature of the waiting list and what offenders end on the list. The vast majority had received short prison sentences for minor offenses up to a few months. If those eligible for community service and persons who had already left Iceland are subtracted, the waiting list could be shortened to less than 300 waiting for their sentence to be processed and implemented by prison authorities. Yet, some of them, up to 30 persons, had been on this list for more than three years. The commission, in turn, formulated a few recommendations to help process these cases more effectively. The proposals aimed at seeking several non-custodial options as an alternative to serving time in prison. 
First, to allow more community service instead of serving time in prison. Those with up to a two-year unconditional prison sentence, instead of one year, should be entitled to apply for community service. Second, restorative justice measures to be offered to a larger degree and permanently instituted to the penal code. Third, suspended punishment should not only be possible for young offenders but should include all age groups. Release on parole after half term served in prison is to be a main rule except for the most serious crimes. Drug crimes, production, importation and selling drugs, however, are not to be included. In most drug cases of these types, parole is only possible after two-thirds of the sentence is served in prison, showing how seriously Icelandic authorities view drug crimes. Treatment options are to be used more frequently, instead of unconditional prison, as a pre-condition for suspended punishment violation. Finally, those who have been on the waiting list for more than three years should be pardoned if they meet certain criteria. No other unfinished criminal cases should be active in the system. With all, or most of these proposals enacted, the group estimated a significantly shorter list and waiting period to be shortened as well. The justice minister welcomed all these recommendations at a press conference (Justice Ministry, 2020) and announced plans to implement them. As a case in point, plans to pardon all those who have been on the list for three years or longer are now in the making (World News, 2020).

\section{Concluding Remarks}

Iceland is a small and relatively homogenous island nation in the North Atlantic and has for a long time been perceived as a low-crime country (Gunnlaugsson \& Galliher, 2000; Ólafsdóttir \& Bragadóttir, 2006). This view was based on limited research, yet in more recent years has been verified by improved local criminal records. For the most part opinions on crime related matters cannot be divided up along political party lines in Iceland. A push for tougher sentencing has for instance never been prominent in the political debate. However, in recent years the plight of sexual crime victims has increasingly entered the public scene resulting in penal code revisions (Bragadóttir, 2018). Drug use and drug trafficking has for a long time been a profound concern in Iceland. Punitive measures in fighting the drug problem have been supported by both the public and local authorities (Gunnlaugsson \& Galliher, 2000). In most recent years however, signs of a shift toward treating drug addiction as a health problem instead of a crime, can be detected in Icelandic society (Gunnlaugsson, 2015).

Iceland has experienced both internal and external changes in recent years. Iceland has opened to the outside world and reflected, among other things, on an influx of new immigrants and foreign visitors. On the heels of these social changes, crime concerns have also deepened, especially towards drugs 
and violence (see also Gunnlaugsson, 2011). This shift can be demonstrated in crime control developments, where both drug and violent offenders have taken more space in the prison system in the new millennium. Moreover, the number of criminal court decisions had also gone up until 2013, when it levelled off, before reaching a new peak in 2019.

The growing number of criminal court sentences with the total in sentencing length increasing is not vastly different from crime control developments in many other countries in Western Europe in late modernity (Garland, 2001; Nelken, 2009; Wacquant, 2009). This mood towards increased and somewhat longer sentencing practices levelled off for the most part in Western Europe in the new millennium, reaching the shores of Iceland a bit later. It was most pronounced for drug offences (Gunnlaugsson, 2015) and sexual crimes (Bragadóttir, 2018), both offences receiving stiffer penalties in most recent years. Punitive practices against specific crimes are, therefore, not only confined to large, heterogenous and complex industrial nations but can also be detected in small and closely knitted societies such as Iceland. This penal development coincides with broad societal changes taking place in Iceland, when the nation increasingly entered the global community.

Yet, Iceland still possesses qualities, setting the country apart from many other Western nations, with its low prison population and relatively lenient penalties. In this vein, Iceland might be close to what Pratt (2008a; 2008b) describes as Scandinavian exceptionalism, with consistently low rates of imprisonment and relatively short sentences. Prisons in Iceland are small, even tiny, with two of the four prisons virtually open. Prison populations are mixed in terms of age, nationality and type of crime, but relationships between staff and inmates tend to be cordial and positive in Iceland (Pakes, 2020). Moreover, tolerating the long prison waiting list, implicitly suggests little or no discomfort, with many convicts simply going back home after receiving their prison sentence to serve their term several months later (or even a few years later), showing that crime and criminals are, in many cases, not greeted with a toxic mix of fury and fear (Pakes \& Gunnlaugsson, 2018). The positive reactions of the justice minister toward the prison commission's proposals are also informative, suggesting a policy tendency toward seeking non-custodial options to solve the waiting list crisis instead of calling for more prison spaces.

What undermines penal exceptionalism for Iceland, however, are several factors. The local prison system has, for a long time, suffered from serious underfunding (State National Auditor Office, 2010). A notable lack of professional help characterises local prisons, with only one or two psychologists and social workers serving the entire prison population in 2017 (RÚV, 2017a). As for educational opportunities, more prison inmates have been studying while in prison, in recent years. Yet, more funds are needed, and a call for a fully thought-out educational policy has been put forward by the director of prison studies (Porkelsson, 2017). 
More recently, however, positive signs can be detected regarding prisoners in Iceland, suggesting a shift toward betterment and rehabilitation policies. In December of 2019 for instance, the minister of health made access to psychiatric services for inmates more available than before (Kolbeinsson, 2019). Moreover, the minister of social affairs announced plans to support ex-prisoners to adjust to society after completion of their sentence (Pétursdóttir, 2019). Time will tell how far-reaching these plans materialise in practice. These measures understandably need funding and professional help often found lacking. Yet, they show rehabilitative sentiment and betterment ideals instead of punitive measures and practices.

A relatively new prisoners' society, Afstaða, has also been very active and vocal in most recent years. They have openly criticised local authorities for not paying enough attention to rehabilitation and betterment of prisoners, interestingly looking at the Norwegian penal system for inspiration. A few years ago, Afstaða opened a Facebook group where their issues and objectives are regularly covered and updated (Afstaða, 2020). Most recently, Afstaða voiced concerns about the well-being of inmates during the world pandemic (Árnason, 2020). Outside visits were banned or limited, making family visits difficult, if not impossible, during the COVID-19 crisis. More inmate access to computers and social media was requested as an attempt to help maintain family relations.

It may be popular, in some circles, to mete out tougher court sentences and raise punishment levels, at least for specific crimes, but it is also costly to institutionally meet this challenge. Pressure to tackle and resolve penal developments by providing new prison facilities has proved to be difficult for Iceland due to the tight fiscal policy practiced by the state. Yet, to meet demand for tighter crime control and the long waiting lists accumulating in the prison system, more prison expenditures have proved to be unavoidable for Iceland, as shown in the new Hólmsheiði Prison. The decision to close the small Akureyri Prison in 2020, clearly shows economic concerns. Using the same funds, including the Akureyri budget, larger prisons reportedly can be used to a larger degree than before, incarcerating 30 inmates instead of ten in Akureyri.

The lesson from Iceland, however, shows us that a penal challenge of this type can also be met by offering different types of non-custodial sanctions. Push for this development might be cost driven, being less expensive than imprisonment, and, therefore, economically and politically attractive. Yet, this policy outcome also opens other prison alternatives and possible reform outside prison walls.

At the same time, it is important that Iceland continues to develop innovative alternatives to serving time in prison, which will both reduce prison expense and replace punishment with rehabilitation. These measures could include meting out more paroles, probation, community service, half-way houses and electronic monitoring, including treatment programs - instead 
of serving time in prison. Here, the research community can serve a vital role by exploring and testing various prison alternatives.

In this respect, it is worth stressing that non-custodial sanctions have not led to any higher recidivism rates than imprisonment (Kury \& Shea, 2011; Yukhnenko et. al., 2019). Despite different crime policies, Nordic nations are ideal research sites with generally low prison populations and well-known welfare systems, offering an important lesson to international comparative research.

Kontaktoplysninger

Helgi Gunnlaugsson: helgigun@hi.is

\section{References}

Afstaða. (2020). Facebook page of a local prisoner society. Accessed October 23, 2020. https://www.facebook.com/afstada/

Arnarsson, S. (2017, March 27). Fangelsið hálftómt en biðlistinn lengist (Prison half empty but waiting list longer). Visir.is. Accessed February 12, 2018.

http://www.visir.is/g/2017170329043/fangelsid-halftomt-en-bidlistinn-lengist

Árnason, E. p. (2020). Sjaldan verið erfiðara að vera fangi (Rarely ever been so difficult being a prisoner). Fréttablaðið, October 5, 2020. Accessed October 23, 2020.

https://www.frettabladid.is/frettir/sjaldan-verid-erfidara-ad-vera-fangi-islandi/

Baumer, E., Wright, R., Kristinsdóttir, K. and Gunnlaugsson, H. (2002). Crime, shame and reintegration: The case of Iceland. British Journal of Criminology, 43(1), 40-59. https://doi.org/10.1093/bjc/42.1.40

Bragadóttir, R. (2018). Nauðgun og önnur brot gegn kynfrelsi fólks (Rape and other sexual offences). Reykjavík: Codex.

Ciric, J. (2020). Prison closure in Akureyri faces oppositon. Iceland Review, July 9, 2020. Acessed October 21, 2020:

https://www.icelandreview.com/politics/prison-closure-in-akureyri-faces-opposition/

Friðriksson, Ó. (2017). Metfjöldi erlendra ríkisborgara (Record number of foreign citizens). Morgunblaðið, p. 4.

Garland, D. (2001). The Culture of Control: Crime and Social Order in Contemporary Society. Chicago: University of Chicago Press.

https://doi.org/10.7208/chicago/9780226190174.001.0001

Gunnlaugsson, H. (2011). Criminal Punishment in Iceland in the New Millennium. In Kury, H. and Shea, E. (eds.). Punitivity International Developments, Vol. 3: Punitiveness and Punishment, 2011: 43-60. Bochum: University Press Brockmeyer.

Gunnlaugsson, H. (2015). Drug use and drug controls in Iceland: An historic paradigm in sight? In Giertsen, H. and Gunnlaugsson, H. (eds.). Drugs: What is the Problem and How Do We Perceive it? Policies on Drugs in Nordic Countries. NSfK Working Group Report, pp 90-103. Århus: Scandinavian Council for Criminological Research.

Gunnlaugsson, H. (2019). Crime and criminal justice in Iceland. In Lauritsen (ed.) Crime and Crime Control in Four Nordic Island Societies: The Faroe Islands, Greenland, Iceland and the Åland Islands, pp 47-62. Århus: Scandinavian Research Council for Criminology. Gunnlaugsson, H. and Galliher, J.F. (2000). Wayward Icelanders: Punishment, Boundary Maintenance, and the Creation of Crime. Madison: University of Wisconsin Press.

Justice Ministry, (2020). Kynnti aðgerðir til að stytta boðunarlista (Introduced action plans to shorten waiting-list). June 29, 2020. Accessed October 23, 2020:

https://www.stjornarradid.is/gogn/rit-og-skyrslur/stakt-rit/2020/06/29/Kynnti-adgerdir-til-ad-stytta-bodunarlista/ 
Justice Ministry Report, (2020). Tillögur starfshóps dómsmálaráđherra til aðgerða sem stytta eiga boðunarlista til afplánunar refsinga (Justice Minister's commission report to shorten the list awaiting completion of punishment). Reykjavík: Stjórnarrád Íslands, dómsmálaráđuneytið. Accessed October 21, 2020:

https://www.stjornarradid.is/library/04-Raduneytin/Domsmalaraduneytid/Till \%c3\%b6gur\%20starfsh\%c3\%b3ps\%20d\%c3\%b3msm\%c3\%a1lar\%c3\%a1\%c3\% b0herra\%20til\%20a\%c3\%b0ger\%c3\%b0a\%20sem\%20stytta\%20eiga\%20bo\%c3 \%b0unarlista\%20til\%20afpl\%c3\%a1nunar\%20refsinga.pdf

Kolbeinsson, J. B. (2019). Fangar fá aðgang að geðlæknum: Ég fékk tár í augun (Access of prisoners to psychiatrists: Brought tears to my eyes). RúV. December 5, 2019. Accessed October 23, 2020:

https://www.ruv.is/frett/fangar-fa-adgang-ad-gedlaeknum-eg-fekk-bara-tar

Kristoffersen, R. (2013). Relapse study in the correctional services of the Nordic countries: Key results and perspectives. Eurovista. 2(3): 168-176.

Kury, H. and Shea, E. (2011). Punitivity and Punishment: An Introduction, pp. 7-20. In Punitivity International Developments. Vol 3: Punitiveness and Punishment. Kury, H. and Shea, E. (eds). Bochum: Universitatsforlag Dr. N. Brockmeyer.

Lauritsen, A. N. (ed.) (2019). Crime and Crime Control in Four Nordic Island Societies: The Faroe Islands, Greenland, Iceland and the Åland Islands. Århus: Scandinavian Research Council for Criminology.

Nelken, D. (2009). Comparative criminal justice. European Journal of Criminology 6(4), 291-311. https://doi.org/10.1177/1477370809104684

Ólafsdóttir, H. and Bragadóttir, R. (2006). Crime and criminal policy in Iceland: Criminology on the margins of Europe. European Journal of Criminology, 4 (3): 221-253. https://doi.org/10.1177/1477370806061977

Ólafsdóttir, K. (2020). Loka fangelsinu á Akureyri (Akureyri Prison to be closed). Visir.is, July 6, 2020. Accessed October 21, 2020: https://www.visir.is/g/20201988680d/loka-fangelsinu-a-akureyri

Pakes, F. and Gunnlaugsson, H. (2018). A more Nordic Norway? Examining prisons in 21st century Iceland. The Howard Journal of Crime and Justice. 57(2), 137-151. https://doi.org/10.1111/hojo.12244

Pakes, F. (2020). Old-fashioned Nordic penal exceptionalism: the case of Iceland's open prisons. Nordic Journal of Criminology, 21: 1-16. Accessed October 21, 2020: https://doi.org/10.1080/2578983X.2020.1809199 https://www.tandfonline.com/doi/full/10.1080/2578983X.2020.1809199

Pétursdóttir, L. V. (2019). Fimmtungur fanga aftur í fangelsi innan tveggja ára (One-fift of prisoners return to prison within two years). Visir.is, December 12, 2019. Accessed October 23, 2020:

https://www.visir.is/g/2019191219649/fimmtungur-fanga-aftur-i-fangelsi-innan-tveggja-ara

Pratt, J. (2008a). Scandinavian exceptionalism in an era of penal excess: Part I: The nature and roots of Scandinavian exceptionalism. British Journal of Criminology 48(2), 119-137. https://doi.org/10.1093/bjc/azm072

Pratt, J. (2008b). Scandinavian exceptionalism in an era of penal excess: Part II: Does Scandinavian exceptionalism have a future? British Journal of Criminology 48(3), 275-292. https://doi.org/10.1093/bjc/azm073

Prison Bill. (2016). Parliamentary file 1025, legislative body, laws on punishment, case no. Law no 15, March 23, 2016. 332, Parliamentary File 1025, 145. Legislative body case no. 332 332. case: completion of sentences (Full Bill).

Law no. 15. Accessed October 21, 2020: http://www.althingi.is/altext/145/s/1025.html.

Prison and Probation Administration. (2020). The Prison and Probation Administration Home Page. Accessed October 21, 2020 from:

https://www.fangelsi.is/english 
RÚV, (2017a). Einn sálfræðingur sinnir 180 föngum (One psychologist serves a total of 180 inmates). RÚV. January 31, 2017. Accessed October 23, 2020: https://www.ruv.is/frett/einn-salfraedingur-sinnir-180-fongum

RÚV, (2017b). Kastljós í kvöld: einangrun mannréttindabrot (Focus tonight: solitary confinement a human rights violation). RúV. May 7, 2017. Accessed December 4, 2020 : https://www.ruv.is/frett/kastljos-i-kvold-einangrun-mannrettindabrot

State National Auditor Office, (2010). Skýrsla til Alpingis: Skipulag og úrræði í fangelsismálum (Report to Alpingi: Structure and prison policy measures). Reykjavík: Ríkisendurskoðun. Accessed October 28, 2020:

https://rikisendurskodun.is/wp-content/uploads/2016/01/fangelsismal.pdf

Statistics Iceland, (2020). Immigrants 15,2\% of the population of Iceland. Accessed September 17, 2020:

https://statice.is/publications/news-archive/inhabitants/immigrants-and-personswith-foreign-background-2020/

Yukhnenko, D., Wolf, A., Blackwood, N. and Fazel, S. (2019). Recividism rates in individuals receiving community sentences: A systematic review. PloS One 14(9). Accessed October 23, 2020:

https://www.psych.ox.ac.uk/publications/1055789 https://doi.org/10.1371/journal.pone.0222495

Wacquant, L. (2009). Punishing The Poor: The Neoliberal Government of Social Insecurity. London: Duke University Press.

https://doi.org/10.1215/9780822392255

World News, (2020). Vill náda pá sem beðið hafa lengi eftir afplánun (Plans to pardon all who have waited a long time for the completion of their sentence). October 3, 2020. Accessed October 23, 2020:

https://theworldnews.net/is-news/vill-nada-tha-sem-bedid-hafa-lengi-eftir-afplanun

World Prison Brief. (2020). Prison Studies. Accessed August 27, 2020:

https://www.prisonstudies.org/highest-to-lowest/prison_population_rate?field_region_ taxonomy_tid=All

Porkelsson, G. (2017). Er ekkert að gera í fangelsunum? (Not much to do in the prisons?) Stundin. Accessed February 12, 2018:

http://stundin.is/pistill/er-ekkert-ad-gera-i-fangelsunum/. 